\title{
THE SYRIAC ARISTOTLE BETWEEN ALEXANDRIA AND BAGHDAD ${ }^{1}$
}

\author{
John W. Watt, Cardiff University \\ (WattJ@cardiff.ac.uk)
}

\begin{abstract}
The efflorescence of philosophy in Arabic in ninth century Baghdad shows a clear relationship to the philosophical work done in Greek in late antique Alexandria, as well as some significant differences. In both locations there was intense interest in Aristotle, though in Baghdad much less in Plato than had been the case in Alexandria. Less is known about philosophy in the intervening period, but the presence of Syriac philosophers both in sixth century Alexandria and eighth-to-tenth century Baghdad raises the possibility that the Syriac tradition may have been a conduit between the two. This article surveys the work of Sergius of Reshaina, an alumnus of Alexandria and the first known Syriac writer on Aristotle, in its relation to his Alexandrian masters, the evidence for Syriac engagement with Aristotelian philosophy in the subsequent two centuries, and the Syriac contribution to Aristotelian philosophy in Abbasid Baghdad. While a continuous tradition of Syriac interest in Aristotle, clearly linked in many of its representatives to the Christianised Neoplatonism of Pseudo-Dionysius, does not exclude the possibility that other aspects of late antique Greek thought may have found their way into Arabic through other channels, such as the Levantine Greeks on which al-Kindī depended for his Arabic translations, or even the alleged Neoplatonists of Harran, the Syriac focus on Aristotle, from Sergius of Reshaina in the sixth century to Abu Bišr Mattā and the Baghdad Aristotelians in the tenth, most convincingly accounts for the dominant position he held in Islamic philosophy.
\end{abstract}

Throughout late antiquity there was a lively culture of philosophical study and writing in Alexandria, particularly following the departure of some philosophers from Athens. In the ninth and tenth centuries CE a comparable endeavour could be found in Baghdad. In Alexandria the medium of philosophical discourse was

\footnotetext{
${ }^{1}$ Various portions of this paper were presented at the conference in London in December 2012 to celebrate the publication of the hundredth volume in the series of the Aristotelian Commentators in Translation directed by Richard Sorabji, at the annual meeting of the International Society for Neoplatonic Studies in Cardiff in June 2013, and at a workshop of the Max-Planck-Institut für Wissenschaftsgeschichte in Berlin in August 2013 as part of its project on the Aristotelization of the world. I am very grateful to Richard Sorabji, Josef Lössl, and Sonja Brentjes for the respective invitations to these meetings, and to participants in them for their comments on the presentations. Abbreviations, and full details of primary sources cited herein in short form, are given at the conclusion of the article.

John Watt, "The Syriac Aristotle Between Alexandria and Baghdad," in: Journal for Late Antique Religion and Culture 7 (2013) 26-50; ISSN: 1754-517X; Website: http://www.cardiff.ac.uk/clarc/jlarc
} 
Greek, in Baghdad it was Arabic; but despite the difference in language, a certain similarity between the two is quite clear. In both locations there was intense interest in the works of Aristotle, and in both locations, the philosophers who interpreted Aristotle's writings did so within the conceptual framework of Neoplatonism. For the historian of philosophy, an obvious question thus presents itself: how did this similarity come about? And what happened in the interval, not only the temporal interval, but also the spatial interval? In a famous paper presented at the Prussian Academy in Berlin in 1930, the historian of medicine Max Meyerhof offered an enticing answer to these questions. ${ }^{2}$ Arguing from a section within the History of the Physicians, the author of which, Ibn Abī Ușaibi 'a, identified as coming from a work dealing with the appearance of philosophy in Islam by al-Fārābīi, ${ }^{3}$ Meyerhof proposed that the School of Ammonius in Alexandria did not die out in subsequent years, but at some point after the Muslim conquest of the Near East transferred itself first to Antioch and later to Harran, from where a few of its members finally settled in Baghdad.

For many years Meyerhof's paper was thought to provide a satisfactory answer to the question as to how late antique Greek philosophy found new life in Abbasid Baghdad, but the evidence for his theory was highly suspect and his solution has now been universally abandoned. I mention it here because its popularity for many years alerts us to the fact that the questions it proposed to solve do not disappear merely because the solution he offered turned out to be untenable. These questions still exist. Did the Arab interest in Greek philosophy emerge without immediate antecedent in the late eighth or ninth century, and if so, why did it closely reflect the Neoplatonic Aristotelianism of late antiquity, rather than the wider range of Greek philosophy available in (unread) manuscripts in Byzantium or elsewhere, on which, on this assumption, the Arabs would have been entirely dependent? Alternatively, did it spring from a living tradition of philosophy in the region, a tradition going back to late antiquity?

My initial characterisation of late antique philosophy as purely Greek, and the philosophy of Abbasid Baghdad as Arabic, was not quite the whole truth. Among the students at Alexandria there were also Syrians and Armenians, and philosophy was studied in Baghdad not only in Arabic, but also in Syriac. Traditionally Syrians (that is, those who used the Syriac language) have been considered, even if in a rather undefined way, as "intermediaries" between Greeks and Arabs, and indeed in a purely philological sense this is undeniably the case. The Syrians were the master translators by whom most of the Arabic translations of Greek philosophy were made, either from Greek, or sometimes from Syriac versions.

\footnotetext{
${ }^{2}$ Meyerhof, M., "Von Alexandrien nach Bagdad," Sitzungsberichte der preussischen Akademie der Wissenschaften. Philosophisch-Historische Klasse 23 (Berlin, 1930), pp. 389-429.

${ }^{3}$ Ibn Abī Ușaibi‘a, vol. II, pp. 134-5 Müller.

John Watt, "The Syriac Aristotle Between Alexandria and Baghdad," in: Journal for Late Antique Religion and Culture 7 (2013) 26-50; ISSN: 1754-517X; Website: http://www.cardiff.ac.uk/clarc/jlarc
} 
One school of thought, however, would limit their "intermediate" role merely to their translation activity, and indeed attribute even that not primarily to an interest in the texts themselves, but only to servicing an Arab interest which had arisen independently of them. On this view, philosophy had been as good as dead in the Near East (as elsewhere) between the sixth century (or earlier) and the late eighth or ninth, and Syriac involvement with the subject during the Baghdad period was merely a by-product of the Arabic interest, separate in all but the most superficial aspects from the Syriac Aristotelianism of late antiquity. ${ }^{4}$ This paper in contrast offers a presentation of the evidence for the alternative interpretation, namely, that philosophy remained very much alive in the Near East during that period, and that its impressive flowering in Abbasid times did not spring from a desert, but from fertile soil. On this interpretation, it is reasonable to suppose that among Abbasid Arabs familiar with Syrians, the Syriac philosophical tradition was one of the factors which gave rise to Graeco-Arabic philosophy, while it can also be true that the stimulus of the developing Arab interest enlivened and broadened the older Syriac one.

A key difference between the focus of philosophical study in late antique (sixth century) Alexandria and that of Abbasid Baghdad is the near (albeit not quite) total absence of Plato from the latter. Not only in late antique Greek philosophy but also in the Byzantine renaissance, while Aristotle was of course well known, Plato was held in higher esteem. By contrast, the dominant position of Aristotle both in preAbbasid Syriac and in Arabic philosophy may well be considered to constitute a powerful argument in support of the view that the preceding Syriac tradition was a significant factor in the early Abbasid period. However, before this thesis can be assessed in greater detail, two preliminary points need to be made. Syrians who studied in Alexandria evidently had to know Greek, and there is no doubt that many Syrians, at any rate among the elites, were effectively bilingual. This was clearly the case with the first known Syriac commentator on Aristotle, Sergius of Reshaina, priest and physician (died 536), who studied in Alexandria and translated many treatises of Galen, as well as one of Alexander of Aphrodisias, and one of pseudo-Aristotle. ${ }^{5}$

It has to be emphasized (against a misconception which is still to be found) that Sergius of Reshaina was not the first translator of any part of the school corpus of Aristotle; but rather, while he did write his commentary on the Categories in Syriac, he expected his readers, if they wished to consult the text of Aristotle themselves, to read it in the Greek. The earliest translation of Aristotle's Categories into Syriac, which remains anonymous, was probably made after Sergius' commentary, perhaps

\footnotetext{
${ }^{4}$ Cf. Gutas, D., Greek Thought, Arabic Culture (London and New York, 1998), pp. 20-22, 62, 133, 137-41; Id., "Origins in Baghdad," in: Pasnau, R. (ed.), The Cambridge History of Medieval Philosophy (Cambridge, 2010), pp. 11-25.

${ }^{5}$ Cf. Hugonnard-Roche, H., La logique d'Aristote du grec au syriaque (Paris, 2004), pp. 123-31. John Watt, "The Syriac Aristotle Between Alexandria and Baghdad," in: Journal for Late Antique Religion and Culture 7 (2013) 26-50; ISSN: 1754-517X; Website: http://www.cardiff.ac.uk/clarc/jlarc
} 
in response to a demand created by its appearance; but whatever the chronological relation between the commentary and the translation, it is certain that Sergius did not assume that his readers would have this translation. ${ }^{6}$ Knowledge of Greek remained common among the Syriac elites during the seventh and eighth centuries. The tradition we label "Syriac" was thus largely, though not exclusively, a bilingual Graeco-Syriac tradition, and the majority of its prominent members were familiar with both languages. Some texts were translated for the benefit of those who knew little or no Greek, but the bilingual scholars had Greek texts as well as Syriac texts at their disposal, and it is not necessary to assume that they translated everything that they knew or studied.

In the ninth century many (majuscule) Greek manuscripts were still available in the region, as Hunain's risāla shows (as regards Galen), ${ }^{7}$ and presumably they had not been preserved simply as pious secular relics, but been actively read and studied. Only when the knowledge of Greek became rare even among the scholarly elite were Greek manuscripts discarded or reused, as occurred from the ninth to eleventh centuries. ${ }^{8}$ When therefore we find knowledge of Greek commentators among learned Hellenist Syrians such as Jacob of Edessa, we may not be able to determine whether they were consulting a Greek or Syriac text, or possibly both, unless we have some explicit evidence to settle the matter. The decline of Greek among the Syriac scholarly elite was particularly precipitate during the ninth century, and that in turn is likely to have been a factor in the corresponding increasing volume of Greek-to-Syriac translations. ${ }^{9}$

The second preliminary point concerns the limited quantity of Syriac manuscript evidence extant from that period. Almost all known Syriac manuscripts written prior to the thirteenth century come from a single monastic library, that of Dayr al-Suryan in Egypt. ${ }^{10}$ Of course literary studies of the ancient world are generally based on manuscripts copied from their earlier exemplars by scribes living long

${ }^{6}$ Cf. King, D., The Earliest Syriac Translation of Aristotle's Categories (Leiden, 2010), pp. 12$14,30-35$.

${ }^{7}$ Hunain, Risāla.

${ }^{8}$ Cf. Brock, S. P., "A Syriac Intermediary for the Arabic Theology of Aristotle? In Search of a Chimera," in: D'Ancona, C. (ed.), The Libraries of the Neoplatonists (Leiden, 2007), pp. 300-301.

${ }^{9}$ Cf. Strohmaier, G., "Hunain ibn Ishāa. An Arab Scholar Translating into Syriac," Aram 3 (1991), pp. 167-8: "The need for translations occurs in general when society assumes an interest in foreign literature of any kind. This need, on the other hand, does not arise when the prospective readers are bilingual ... (as) holds true for Syrian territory before the Arab invasion. ... it was only at the end of the eighth century under Arab rule and again in the East that a second wave of medical translations came into being. ... The first cause of this new development lay in the fact that the old Syro-Greek bilingualism had further declined in favour of the now obligatory Syro-Arabic bilingualism."

${ }^{10}$ These manuscripts are now located in the British Library (BL) and in the Vatican Library. On the importance of the Dayr al-Suryan collection cf. Brock, S. P., "Without Mushē of Nisibis, Where Would We Be?" in: Ebied, R. and H. Teule (eds.), VIII Symposium Syriacum = Journal of Eastern Christian Studies 56 (2004), pp. 15-24. Cf. also Coakley, J. F., "Manuscripts," GEDSH, pp. 262-4. John Watt, "The Syriac Aristotle Between Alexandria and Baghdad," in: Journal for Late Antique Religion and Culture 7 (2013) 26-50; ISSN: 1754-517X; Website: http://www.cardiff.ac.uk/clarc/jlarc 
after the period of the authors. But after the thirteenth century, Syriac scribes had little interest in copying texts of Aristotle or early Greek or Syriac commentators. If they copied any philosophical texts at all, it was more likely to be those of the compendium of Aristotelian philosophy by the thirteenth century polymath Bar Hebraeus. Much Aristotelian material therefore that was once available in Syriac, originating both before and during the Abbasid era, has thus not come down to us, and is known only either from references in Arabic or from a brief mention or citation in other Syriac works. ${ }^{11}$ For example, there is no manuscript extant of Aristotle's Poetics in Syriac, but the single manuscript of an Arabic version states that it was translated from Syriac, as does the notice on the Poetics in the Fihrist of Ibn al-Nadim, and an extract from a Syriac version is quoted by the thirteenth century Syriac writer Jacob bar Shakko in his philosophical compendium entitled The Book of Dialogues. ${ }^{12}$ The situation in this respect is not completely different from that in Arabic, where there are many more manuscripts extant of the compendia and commentaries by Avicenna and Averroes than of Aristotle or the later Greek commentators.

These two points may be illustrated in connection with the East Syrian patriarch Timothy I, who resided in Baghdad. Some time at the end of the eighth century he commissioned a priest named Sergius to send him a memorandum of the books in the library of the West Syrian monastery of Mar Zina (in northern Iraq), where he thought Sergius might find (inter alia) "the commentary of Olympiodorus on the books of the logic, or of Stephanus or of Sergius or of Alexander ..."13 The text is unfortunately too brief for us to ascertain whether Timothy knew some of the works of the commentators here mentioned and was hoping to find more, or whether he only knew of them from the hearsay of others. However, even if the latter was the case, the mention of Sergius among the three Greek writers strongly suggests that these "others" were Syrians, among whom all four commentators were known. It is possible that Syriac versions were known of the three Greek commentators, but since Timothy tells us (in the same letter) that while he considered Syriac his native language he had also studied Greek and Arabic, ${ }^{14}$ it is also possible that his hope was for Sergius to find texts of these three either in Syriac or in Greek.

In another letter Timothy asks a different correspondent, Pethion, to look in the monastery of Mar Mattai for commentaries or scholia on the Topics, Sophistical Refutations, Rhetoric and Poetics, whether in Syriac or not (for which we can only

\footnotetext{
${ }^{11}$ Cf. Watt, J. W., "The Syriac Translations of Hunayn ibn Ishāq and their Precursors," in: Tamcke, M. (ed.), Proceedings of the German Syrologentag, Göttingen, December 2011 (Wiesbaden, forthcoming).

${ }^{12}$ Cf. Tarán, L. and D. Gutas, Aristotle. Poetics (Leiden and Boston, 2012), pp. 92, 96-7, 98-103.

${ }^{13}$ Timothy, Ep. 19, p. 129 (text)/86 (version) Braun.

${ }^{14}$ Ibid., p. 127/85.

John Watt, "The Syriac Aristotle Between Alexandria and Baghdad," in: Journal for Late Antique Religion and Culture 7 (2013) 26-50; ISSN: 1754-517X; Website: http://www.cardiff.ac.uk/clarc/jlarc
} 
assume Greek as the alternative), ${ }^{15}$ and in yet another letter he discusses passages in the Greek and in Athanasius of Balad's Syriac versions of the Posterior Analytics and the Topics. ${ }^{16}$ Athanasius' Syriac versions of Aristotle have not survived, and are known only from this mention by Timothy and from some references to their readings in the marginalia of the Paris Arabic manuscript of the Organon (Paris, Bibliothèque nationale française, MS. Arabe 2346). ${ }^{17}$

Translations, therefore, whether extant or (as is more often the case) only known through references in other writings, are neither the only surviving evidence for Syriac interest in Aristotle, nor are they the only form which that interest took. Nevertheless, they are important on both these counts. It is hardly credible that translations of treatises of Aristotle would have been made merely for the private satisfaction of the translator himself if the spirit so moved him. ${ }^{18}$ Such major tasks would have been undertaken only by those who were not only deeply interested in the subject of the texts, but also greatly concerned that they be taught to others, in this case to those who could not read them in Greek, or only read the Greek with difficulty. Where Aristotle was taught in Syriac, and especially at the monastic school of Qenneshre, which appears to have been the main centre for such studies, it may well be that he was expounded in lectures in Syriac to students who, in the early period at least, were expected to read the texts of the Philosopher himself in Greek. Then, over time, translations were provided of some of those texts, for students whose Greek was insufficient or nonexistent. Meanwhile the teachers, and those students who continued to have an adequate knowledge of Greek, could have employed the works of the Greek commentators, even if they had not been translated. ${ }^{19}$

Sergius of Reshaina's intention was to comment on the entire Aristotelian school corpus from the Categories to the Metaphysics, but how much of it he achieved we

\footnotetext{
${ }^{15}$ Timothy, Ep. 43, p. 66 (text)/49-50 (version) Heimgartner; translation and commentary also by Brock, S. P., "Two Letters of the Patriarch Timothy from the Late Eighth Century on Translations from Greek," Arabic Sciences and Philosophy 9 (1999), pp. 236, 241-2.

${ }^{16}$ Timothy, Ep. 48, pp. 89-92 (text)/74-7 (version) Heimgartner; Brock, 'Two Letters', pp. 2389, 245-6.

${ }^{17}$ Cf. Watt, J. W., "Al-Farabi and the History of the Syriac Organon," in: Kiraz, G. A. (ed.), Malphono w-Rabo d-Malphone. Studies in Honor of Sebastian P. Brock (Piscataway, 2008), pp. 755-8 [reprinted separately in Analecta Gorgiana 129, Piscataway, 2009].

${ }^{18}$ Against Gutas, "Origins in Baghdad," p. 15; (Tarán and) Gutas, Aristotle. Poetics, p. 86, n. 18. Cf. my article "Syriac Aristotelian Tradition and the Syro-Arabic Baghdad Philosophers," in: Janos, D. (ed.), Falsafah between Christianity and Islam (Leiden, forthcoming).

${ }^{19}$ Cf. Furlani, G., "La versione e il commento di Giorgio delle nazioni all' Organo aristotelico," Studi italiani de filologia classica 3 (1923), pp. 305-33; Id., "Sul commento di Giorgio delle nazioni al primo/secondo libro degli Analitici anteriori di Aristotele," Rivista degli studi orientali 20 (194243), pp. 47-64/ 229-38.

John Watt, "The Syriac Aristotle Between Alexandria and Baghdad," in: Journal for Late Antique Religion and Culture 7 (2013) 26-50; ISSN: 1754-517X; Website: http://www.cardiff.ac.uk/clarc/jlarc
} 
do not know, for only that on the Categories is extant. ${ }^{20}$ The intention is clearly formulated in this work, where he writes that after his exposition of the logical treatises of Aristotle "we will go on to his other treatises, those on the parts of practice, (then) physics and mathematics, and (then) the last ones which are called 'divine'."21 The closest affinities of his commentary are with those of Ammonius and Philoponus, and it may therefore be appropriate to consider the commentaries of both Sergius and Philoponus, along with those of Simplicius and Olympiodorus, as independent witnesses to the teaching of Ammonius, supplementing the material contained in the commentary which bears Ammonius' name.

One feature absent from the latter but present in some form in all the others is a comparison between the design and construction of a house and that of Aristotle's logical treatises. The respective aims are in one case protection from rain and in the other the provision of an instrument differentiating truth from falsehood and good from evil. In one an architect first designs the roof, in the other Aristotle first conceived his demonstrations. Subsequently the architect designs supporting walls and foundations, while Aristotle conceived syllogisms, propositions, and simple names. The implementation, however, then has to be in the reverse order from the design; so the building of the house begins with foundations and proceeds to walls and the roof, and Aristotle similarly began with the Categories and proceeded through the De interpretatione and the Prior Analytics to the Posterior Analytics / Apodeictics. The remaining treatises - Sergius mentions those up to the Rhetoric - are those "useful to it [scil. logic] in any way." 22 Clearly, if Sergius knew anything about the "short Organon" (which ended at Prior Analytics I, 7), he had no interest in it. ${ }^{23}$

The Categories was the first work of the curriculum to be studied. Therefore the introductions to it usually provide us with the commentators' understanding of the character and purpose of Aristotelian philosophy as a whole. In the introduction to his commentary, Sergius deals with some of the ten introductory questions seemingly formulated by Proclus and known to the subsequent commentators. Number four in the series, the aim of Aristotelian philosophy, was answered by Ammonius as the ascent to the common arche of all, and by Philoponus, perhaps with a Christian twist, as the knowledge of the archē of all, the creative ("demiurgic"), eternal and unchanging cause of all things, which philosophy

\footnotetext{
${ }^{20}$ The work is not yet edited, but a translation and commentary of the prologue and first chapter can be found in Hugonnard-Roche, La logique, pp. 143-231, and one of chapter two from my hand will appear in Martini C. and E. Coda (eds.), Henri Hugonnard-Roche Jubilee Volume (forthcoming). In the present article I cite the prologue and chapter one from Hugonnard-Roche's translations, and chapter two according to the oldest manuscript, London, British Library, Add. $14,658\left(7^{\text {th }} \mathrm{c}\right.$.).

${ }^{21}$ London, British Library, Add. 14,658 ( $7^{\text {th }}$ c. $)$, fol. $3^{\text {rb }}$.

${ }^{22}$ Ibid., fols. $2^{\text {rb }}-3^{\text {rb }}$. Cf. Philoponus, In Cat., pp. 10,21-11,33 Busse; Simplicius, In Cat., pp. 14,515,8 Kalbfleisch; Olympiodorus, Proleg., pp. 2,10-12; 24,22-29 Busse.

${ }^{23}$ On this subject, cf. my "Al-Farabi and the History of the Syriac Organon." John Watt, "The Syriac Aristotle Between Alexandria and Baghdad," in: Journal for Late Antique Religion and Culture 7 (2013) 26-50; ISSN: 1754-517X; Website: http://www.cardiff.ac.uk/clarc/jlarc
} 
demonstrates to be one and incorporeal. ${ }^{24}$ While the question was not explicitly raised by Sergius, in discussing the divisions of philosophy he declares the aim of theoretical philosophy to be the knowledge (or theoría) of all beings in the world, a clear allusion to one of the definitions of philosophy (usually the first one) in the commentators' prolegomena to philosophy as a whole. ${ }^{25}$ Like the Greek commentators he considers logic an instrument which in the theoretical division of philosophy separates truth from falsehood and ignorance, and in the practical division, good from evil.

In the rhetorical prologue addressed to bishop Theodore of Karkh Juddan, which precedes the stricter philosophical prolegomena, he writes that Aristotle was the origin of all knowledge, not only for Galen and all medical doctors, but also for all subsequent philosophers. ${ }^{26}$ Thus, far from following the usual course of his philosophical masters in asserting the superiority of Plato to Aristotle and treating the Aristotelian curriculum as propaedeutic to the Platonic, he pointedly avoids mention of Plato as "the origin of all knowledge for all subsequent philosophers". In fact, the passage points to Sergius himself as the likely originator of the idea of the dominance of Aristotle prevalent in Syriac philosophy. Sergius does, however, make reference to Plato in another passage of his Commentary, attaching to "Plato and all the Academics" the doctrine of genera and species as demiurgic forms, and setting opposite them "Aristotle and all the Peripatetics, among whom is Alexander of Aphrodisias, who in no way acknowledge these primary forms with the demiurge, but very much hold to those in matter and those in our thought." ${ }^{27}$ Sergius does not explicitly come out against Plato, but merely states the two contrasting positions, nevertheless giving considerably more space to the Platonic. Yet since he had previously told his readers that Aristotle is the origin of all knowledge for all subsequent philosophers, they would surely have assumed they were to believe that Aristotle was right. Why then did he bother to present, at some length, the Platonist position?

To answer this question, let us move on to a further consideration. In addition to the medical and philosophical texts mentioned earlier, Sergius made one other highly significant translation from the Greek: the corpus of Pseudo-Dionysius the Areopagite (hereafter referred to as "Dionysius"). Furthermore, he attached as a prologue to his translation a short treatise which he had composed at an earlier date but which is extant only in this connection. Its original title is therefore unknown, and it is conventionally identified by that given to it by its editor, "A Memra [= Discourse] on the Spiritual Life". In this treatise Sergius identifies seven divisions

\footnotetext{
${ }^{24}$ Ammonius, In Cat., p. 6,9-12 Busse; Philoponus, In Cat., pp. 5,34-6,2.

${ }^{25}$ Cf. Westerink, L. G., Prolégomènes à la philosophie de Platon (Paris, 2003), p. xlix. Syriac $\bar{\imath}$ da' $t \bar{a}$ d-kolhōn hwāyē corresponds to Greek gnōsis pantōn tōn ontōn.

${ }^{26}$ Hugonnard-Roche, La logique, p. 168.

${ }^{27}$ London, British Library, Add. 14,658 ( $7^{\text {th }}$ c. $)$, fols. $5^{\mathrm{rb}}-6^{\mathrm{vb}}$. John Watt, "The Syriac Aristotle Between Alexandria and Baghdad," in: Journal for Late Antique Religion and Culture 7 (2013) 26-50; ISSN: 1754-517X; Website: http://www.cardiff.ac.uk/clarc/jlarc
} 
of theoría. Four of them are easily recognisable as the four principal parts of the Aristotelian curriculum: demonstrations and combinations of worded statements (i.e. logic), theoria of the visible natures (i.e. physics), theoria of the faculties adjoining the visible natures (i.e. mathematics), and theoría pertaining to the hidden substances higher than vision (i.e. metaphysics). Two (i. e. theoría made known in the hidden silence of the intellect without word, and theoría residing in the things which afterwards enter from outside into rational natures through their freedom) are derived from the writings of the Christian spiritual master Evagrius of Pontus. The final and highest division of theoría, echoing Proclus' "flower of the intellect", ${ }^{28}$ is called by Sergius "the finest flower, which by means of all those (already) mentioned touches, as far as is permitted, on the exalted radiance of the hidden divinity." 29 Sergius goes on to declare it "not a knowledge but an excess of ignorance and superior to knowledge,"30 a clear allusion to the negative theology of Neoplatonism, but in this context evidently referring to Dionysius.

We thus have here a two-strand curriculum, one strand of which is Aristotle, as in the Neoplatonic curriculum which Sergius himself studied under Ammonius, the second is constituted not by the Neoplatonic reading of Plato, but by the works of Evagrius and Dionysius, both of whom saw themselves as interpreters of the Bible. This enables us to understand another important passage in Sergius' commentary on the Categories, where he declares that without Aristotle's logic not only medicine and philosophy cannot be understood, but neither "can the true sense be uncovered of the divine Scriptures - unless it should be that someone receives divine ability thanks to the exalted nature of his way of life, with the result that he has no need for human instruction." 31 As in the pagan cursus Plato was held to be incomprehensible without prior study of logic and the rest of the Aristotelian curriculum, so in Sergius' scheme the Aristotelian curriculum appears as the necessary preparation for the Dionysian interpretation of the Bible.

In one sense, therefore, Sergius was a faithful disciple of his Alexandrian masters, in envisioning a curriculum embracing both the Aristotelian corpus from logic to metaphysics and a "higher" corpus leading to "an excess of ignorance superior to knowledge". He does not explain how Aristotelian metaphysics, culminating in the pure self-thinking nous of Metaphysics Lambda, is related to the unknowable but creative Christian divinity of Dionysius. We might reasonably suppose, however, that he conceived it in a fashion analogous to that between Aristotle and Plato in the Alexandrian philosophical tradition, where it was held that Aristotle treated theology from the standpoint of natural philosophy, and thus never fully

\footnotetext{
${ }^{28}$ Proclus, Platonic Theology I, 3, p. 15 Saffrey-Westerink.

${ }^{29}$ Sergius, Memra, $\$ 79$, pp. 122-4 Sherwood.

${ }^{30}$ Ibid., \$80, p. 124 Sherwood.

${ }^{31}$ London, British Library, Add. 14,658 ( $7^{\text {th }}$ c.), fols. $60^{\mathrm{vb}}-61^{\mathrm{ra}}$. Cf. Hugonnard-Roche, H., "Aux origins de l'exégèse orientale de la logique d'Aristote: Sergius de Reš‘aina, médecin et philosophe," Journal asiatique 277 (1989), p. 12.

John Watt, "The Syriac Aristotle Between Alexandria and Baghdad," in: Journal for Late Antique Religion and Culture 7 (2013) 26-50; ISSN: 1754-517X; Website: http://www.cardiff.ac.uk/clarc/jlarc
} 
transcended it, while Plato had treated natural philosophy from the standpoint of theology. ${ }^{32}$ For Sergius, however, the theology beyond Aristotle lay in the Bible, interpreted by Dionysius, who claimed for his interpretation a sacred ecclesiastical tradition, although, as we now know, that tradition was merely an image of the Platonist tradition claimed by Proclus.

Sergius' text gives us no ready answer as to how he came to this position, but it is not too difficult to construct a plausible hypothesis. As a student in Ammonius' school he must surely have come into contact with the writings of Proclus, who was Ammonius' own teacher - even if, whatever the deal was which Ammonius struck with the patriarch in Alexandria, this would have involved some diminution in the teaching of Platonic theology. But while evidently deeply impressed by his teachers, as a Christian he could not accept the pagan implications of the School's Platonic theology. In Dionysius, however, he no doubt found a kindred spirit who shared much with the Neoplatonic theology he had encountered in Alexandria, but in a form he believed consistent with Christianity, with the Bible rather than Plato as the canonical text.

Whether Sergius knew (or guessed) that the supposed "Areopagite" was in reality an admirer of Proclus who had cleverly recast his theology into a Christian form, ${ }^{33}$ or whether already he was of the belief that Proclus had borrowed from "the blessed Dionysius," 34 we may never know. But if the real author of the Dionysian corpus wanted, among other things, to ensure that what he considered valid insights of the pagan philosophical tradition were not swept away by a triumphalist, antiphilosophical Christianity, then Sergius for his part wanted to preserve, in the Syriac sphere, the valuable legacy of the Aristotelian curriculum.

It is in this perspective that we should understand Sergius' guarded reference, mentioned earlier, to "Plato and all the Academics" in connection with the demiurgic forms (paradeigmata). That Sergius to some extent believed in them is highly likely, for Proclus and Dionysius did so, but Dionysius did so in his own Christianised way. Proclus had maintained in commenting on the Timaeus that

The Peripatetics say that there is something separate from matter, but it is not an efficient cause, only a final. And this is why they also removed the paradeigmata

\footnotetext{
${ }^{32}$ Cf. Hadot, I., Simplicius, Commentaire sur les categories, fasc. I (Leiden, 1990), pp. 100, 111112.

${ }^{33}$ Cf. Perczel, I., "Pseudo-Dionysius and the Platonic Theology," in: Segonds A., and C. Steel (eds.), Proclus et la théologie platonicienne (Leuven, 2000), pp. 491-532.

${ }^{34}$ An interpolated passage in John of Scythopolis's Prologue to the Dionysian corpus maintains that Proclus borrowed from Dionysius. The author of the passage may have been Philoponus, Sergius' younger contemporary. Cf. Rorem, P. and J. Lamoreaux, John of Scythopolis and the Dionysian Corpus: Annotating the Areopagite (Oxford, 1998), pp. 106-7. The older Sergius, however, may have known (or guessed) the true direction of the borrowing, for in his lifetime the apostolic credentials of Dionysius were still far from generally accepted; cf. ibid., p. 21-2, 99-106.

John Watt, "The Syriac Aristotle Between Alexandria and Baghdad," in: Journal for Late Antique Religion and Culture 7 (2013) 26-50; ISSN: 1754-517X; Website: http://www.cardiff.ac.uk/clarc/jlarc
} 
("paradigms"), and set at the head of all things an Intellect without multiplicity. Plato, however, and the Pythagoreans hymned the demiurge of the universe as something separate from matter, far removed, the creator of everything and providence of all, and this is the most reasonable view. ${ }^{35}$

In the Divine Names Dionysius wrote:

We say that logoi ("principles") in God, creating the substance of beings and preexisting as a unity, are paradeigmata ("paradigms") - which theology calls proorismoi ("pre-definings") and divine and good acts of will (thelemmata), defining and creating the beings - according to which the Supersubstantial pre-defined and brought about all beings. ${ }^{36}$

The paradeigmata and creative logoi in the divine Intellect of Platonism are thus given a Christian meaning by their "theological" (i.e. biblical) re-designation as divine "pre-definings" in accordance, as John of Scythopolis recognised, ${ }^{37}$ with Romans 8:30 ("whom he pre-defined [proōrisen], those he also called"), and Ephesians 1:5 ("having pre-defined us ... according to the good pleasure of his will").

There is some truth, in other words, in what Platonists asserted in the sphere of theology, in particular their doctrine of God as the efficient cause of the world, not the merely (real or apparent) Aristotelian final cause, but it requires a Christian formulation, as in Dionysius. Sympathetic to Proclus inasmuch as this (pagan) philosopher was the inspiration of - or a borrower from - the Christian Dionysius, he was willing to allow his readers a glimpse into the limitation of Aristotelianism as understood by Proclus (and others) and to signal the opposed virtues of its rival. Yet being on the whole enthusiastic towards the "neutral" Aristotle and critical of the paganism embedded in the Platonic theology of his time, he may also have pondered in his own mind whether Ammonius' interpretation, namely that Plato's paradeigmata were internally created within the divine Intellect, and that Aristotle was in agreement with this, may have been correct. ${ }^{38}$

\footnotetext{
${ }^{35}$ Proclus, In Tim. 1, p. 266,28-267,4 Diehl. English Translation in Sorabji, R., Matter, Space, and Motion. Theories in Antiquity and their Sequel (London, 1988), pp. 251-2.

${ }^{36}$ Dionysius, De Div. Nom. 5, 824C, p. 188,6-10 Suchla.

${ }^{37}$ John of Scythopolis, Scholia, 329B Migne; transl. Rorem and Lamoreaux, John of Scythopolis, p. 222. Cf. Saffrey, H. D., "Nouveaux liens objectifs entre le Pseudo-Denys et Proclus," Revue des sciences philosophiques et théologiques 63 (1979), pp. 13-14.

${ }^{38}$ Much of the passage in Sergius (cf. above, n. 27) depends on Ammonius, In Isag., p. 41,1045,2 Busse. In the course of the latter, Ammonius declares (p. 43,25-44,4) that while Aristotle thinks as a natural philosopher (phusikōs), Plato was a theologian (theologikōs), but the two were in harmony, for Aristotle believed that Plato's demiurgic forms were within, not external to, the demiurgic Intellect. Cf. above, n. 32 and on the whole topic Sorabji, Matter, Space, and Motion, pp. 273-9.

John Watt, "The Syriac Aristotle Between Alexandria and Baghdad," in: Journal for Late Antique Religion and Culture 7 (2013) 26-50; ISSN: 1754-517X; Website: http://www.cardiff.ac.uk/clarc/jlarc
} 
It was one of the merits of Max Meyerhof's 1930 paper that it recognised the argument for a continuous tradition of philosophical study in the Near East was tied up with the question as to whether any teaching institution(s) existed there which could have supported it. Since the demise of his hypothesis concerning the transfer of the School of Alexandria, it has been commonly assumed that some Aristotelian philosophy, at any rate logic of the "truncated Organon", was widely taught in Syriac monastic schools. ${ }^{39}$ This may well be true, but we have no direct evidence for it. We do, however, have convincing indirect evidence for the study of Aristotelian philosophy at one important monastic school, that of Qenneshre on the Euphrates. This monastery, dedicated to St. Thomas, was originally located at Seleucia, the port of Antioch, and thus in Greek-speaking territory. It relocated to Qenneshre around 530 AD for confessional, anti-Chalcedonian reasons, under the leadership of John bar Aphthonia, a native of Edessa, whose literary production, however, appears to have been entirely in Greek. ${ }^{40}$ Bilingualism, therefore, was very much in Qenneshre's "genes". It was well known as a centre of Greek studies in the Syrian-Mesopotamian region, and its transfer to the Euphrates did not cut it off from Greek culture, at least not for many years. ${ }^{41}$ While the evidence for the eastward transfer of the School of Alexandria is flimsy, that for the monastery of St. Thomas is sound.

The reason for believing that Aristotelian philosophy was taught there is that the four most important Syriac Aristotelian scholars of the seventh century were all associated with it at some time. Severus Sebokht wrote on the De interpretatione and the Prior Analytics, ${ }^{42}$ Athanasius of Balad wrote an introduction to logic and translated into Syriac the Eisagogē, the Prior Analytics, the Posterior Analytics, the

${ }^{39}$ Cf. Strohmaier, G., "Von Alexandrien nach Bagdad - eine fiktive Schultradition," in Wiesner, J. (ed.), Aristoteles: Werk und Wirkung. Paul Moraux gewidmet, vol. II (Berlin, 1987), pp. 380-89, esp. pp. 387-8.

${ }^{40}$ Cf. Tannous, J., "Qenneshre" ; Childers, J. W., "John bar Aphtonia," GEDSH, pp. 345-6 and 229 ; Hugonnard-Roche, H., "Le mouvement des traductions syriaques, " Entre Orient et Occident: La philosophie et la science grécoromaines dans le monde arabe, Entretiens sur l'antiquité classique 57 (Geneva, 2010), pp. 57-60.

${ }^{41}$ Cf. Brock, "A Syriac Intermediary for the Arabic Theology of Aristotle?" pp. 299-300. Without pressing the parallel too closely, it is interesting to compare the role of Qenneshre in the maintenance of Greek literary culture in a Syriac-speaking environment with that of the monastery of Fulda in that of classical Latin literary culture in a German-speaking environment during the so-called "Dark Ages". Cf. Smith, J. M. H., Europe after Rome (Oxford, 2005), pp. 47-9.

${ }_{42}$ Although we have a work of Severus only "about the kinds of categorical syllogisms in the Book of Prior Analytics," he describes this as "useful for us and very advantageous towards (the acquisition of) the full knowledge of the logical and demonstrative theoria of what is said in the book of Apodeictics (i.e. the Posterior Analytics)." Cf. Wright, W., Catalogue of Syriac Manuscripts in the British Museum Acquired since the Year 1838 (London, 1870-72), Part 3, p. 1160b. For Severus, therefore, as for Sergius, the point of studying (Categories to) Prior Analytics was to be able to understand the Posterior Analytics. Athanasius of Balad, translator of the four treatises from Prior Analytics through to Sophistical Refutations, was a pupil and confidant of Severus.

John Watt, "The Syriac Aristotle Between Alexandria and Baghdad," in: Journal for Late Antique Religion and Culture 7 (2013) 26-50; ISSN: 1754-517X; Website: http://www.cardiff.ac.uk/clarc/jlarc 
Topics and the Sophistical Refutations, Jacob of Edessa translated the Categories, and George, bishop of the Arabs, translated and wrote commentaries on Categories, De Interpretatione, and the complete Prior Analytics. ${ }^{43}$ Some of these works have survived in manuscripts, others are known only from the references of others, and as was hinted above, failure to take into account the latter group is a principal cause of the misperception concerning the level of Syrians' engagement with philosophy in the pre-Abbasid period, particularly the view that their interest was confined to the "short Organon".

This last point is perhaps worth some elaboration here. The old Anonymous of the Categories is preserved only in a Dayr al-Suryan manuscript. ${ }^{44}$ The version of Jacob of Edessa is preserved in one Dayr al-Suryan manuscript ${ }^{45}$ and several later manuscripts. It is possibly referenced in the Paris Arabic Organon. ${ }^{46}$ The version of bishop George of the Arabs is preserved only in a Dayr al-Suryan manuscript. ${ }^{47}$ Old translations of De Interpretatione and Prior Analytics to I, 7 are preserved in the same Dayr al-Suryan manuscript as Jacob of Edessa's Categories and again in some later ones, but are not mentioned in the Paris Organon. George's translations of De Interpretatione and the complete Prior Analytics are preserved only in the same Dayr al-Suryan manuscript as that of his Categories and again not mentioned in the Paris Organon. A complete translation of the Prior Analytics by Athanasius of Balad (and a later one by Theophilus of Edessa) are mentioned only in the Paris Organon. Athanasius' translation of the Posterior Analytics is mentioned only in the letter of Timothy, the same scholar's version of the Topics is mentioned both by Timothy and in the Paris Organon, and his (and Theophilus' version) of the Sophistical Refutations are mentioned only in the Paris Organon (Theophilus' is also mentioned in the Fihrist). ${ }^{48}$ Commentaries on the De Interpretatione and the Prior Analytics to I, 7 are preserved in three Dayr al-Suryan manuscripts ${ }^{49}$ and in several later ones. A commentary on the complete Prior Analytics is preserved in the already mentioned Dayr al-Suryan manuscript of George. A Rhetoric in Syriac was almost certainly used by Bar Hebraeus, ${ }^{50}$ and a Syriac Poetics with absolute

\footnotetext{
${ }^{43}$ Cf. Reinink, G. J., “Severos Sebokht;” Penn, M. P., “Athanasius II of Balad;” Salvesen, A. G., "Ya'qub of Edessa;" Brock, S. P., "Giwargi, bp. of the Arab tribes," GEDSH, pp. 368, 46, 432-3, and $177-8$.

${ }^{44}$ London, British Library, Add. 14,658 ( $7^{\text {th }}$ c.), edited in King, The Earliest Syriac Translations of Aristotle's Categories.

${ }^{45}$ Rome, Bibliotheca Apostolica Vaticana, Vat. syr. $158\left(9^{\text {th }}-10^{\text {th }}\right.$ c. $)$.

${ }^{46}$ Cf. King, The Earliest Syriac Translations, pp. 21-9; edited by K. Georr, K., Les Catégories d'Aristote dans leurs versions Syro-Arabes (Beirut, 1948).

${ }^{47}$ London, British Library, Add. $14,659\left(8^{\text {th }}-9^{\text {th }}\right.$ c. $)$.

${ }^{48}$ Fihrist, p. 249,27 Flügel, trans. p. 601 Dodge.

${ }^{49}$ London, British Library, Add. $14,660\left(9^{\text {th }}-10^{\text {th }}\right.$ c.); London, British Library, Add. 17,156 (9th c.), and, already mentioned, Rome, Bibliotheca Apostolica Vaticana, Vat. Syr. $158\left(9^{\text {th }}-10^{\text {th }}\right.$ c.).

${ }^{50}$ Cf. Watt, J. W., Aristotelian Rhetoric in Syriac (Leiden, 2005), pp. 6-8, 20-29.

John Watt, "The Syriac Aristotle Between Alexandria and Baghdad," in: Journal for Late Antique Religion and Culture 7 (2013) 26-50; ISSN: 1754-517X; Website: http://www.cardiff.ac.uk/clarc/jlarc
} 
certainty by Bar Shakko and mentioned by the Fihrist and the Paris Organon, ${ }^{51}$ but neither is extant and we cannot tell whether or not these "disputed" members of the Organon were translated into Syriac in the pre-Abbasid period.

In this context it is also worth noting that none of the many Syriac versions of Aristotle and the Greek commentators made by Hunain and Ishāa mentioned in the Paris Organon and the Fihrist is extant. In order therefore to know what was studied by Syrians, both before and also during the early Abbasid period, we have to broaden our enquiry beyond the extant Syriac manuscripts. It would be arbitrary to deduce from three Dayr al-Suryan manuscripts (namely BL Add. 14,660, BL Add. 17,156, and Vat. Syr. 158) that pre-Abbasid Syrians at all times and in all places studied only the short Organon, when another Dayr al-Suryan manuscript (BL Add. 14,659) and the evidence of Timothy and the Paris Organon, not to mention the indications of Sergius and Severus, tell us something quite different.

From the group of three manuscripts mentioned above, only Vat. Syr. 158 includes the complete "short Organon" (i.e. Categories to Prior Analytics I,7), and it uses the translation of the Categories made by Jacob of Edessa (d. 708). Jacob's version was probably made after Athanasius of Balad (d. 687) had rendered Prior Analytics to Sophistical Refutations into Syriac, and all three of these manuscripts are later than Athanasius. From the assemblage of texts copied in manuscripts from other locations (the earliest from the thirteenth century, but the majority much later), we might be justified in making some speculative deductions about the range of philosophical study among some pre-Abbasid Syrians, but would not be entitled to extrapolate these to pronounce judgements that apply to all of them - or indeed to Syrians of the early Abbasid era, for none of these later Syriac manuscripts includes any of the Aristotelian translations of Hunain or Ishāa, or Theophilus of Edessa, or any other Syriac versions from which Abū Bišr Mattā, Yahyyā ibn 'Adī, and Ibn Zur'a (discussed below) made their Syriac-to-Arabic translations. Neither can the oldest manuscript of all, BL Add. 14,658 from Dayr al-Suryan, tell us anything about the range of pre-Abbasid Syriac study of the Aristotelian school corpus, as the only such works with which it deals are the Eisagoge $\bar{e}$ and the Categories. Al-Fārābī's well-known assertion (apud Ibn Ab̄i Ușaibi'a) that Christian bishops forbade the teaching of the Organon beyond the assertoric syllogisms, fanciful as it is, at least has the merit of attempting to justify his claim that quite generally in the Christian era "prior to the coming of Islam" the teaching of logic was confined to the short Organon. The modern hypothesis, by contrast, which dismisses his assertion concerning the bishops but accepts that prior to the Abbasid period all Syrians (including Graeco-Syrians) operated within this confine, provides no credible explanation why all of them should have done so. ${ }^{52}$

\footnotetext{
${ }^{51}$ Cf. above, n. 12.

${ }^{52}$ For a listing of all Syriac manuscripts related to the Organon, including the later ones, cf. Brock, S., "The Syriac Commentary Tradition," in: Burnett, C. (ed.), Glosses and Commentaries John Watt, "The Syriac Aristotle Between Alexandria and Baghdad," in: Journal for Late Antique Religion and Culture 7 (2013) 26-50; ISSN: 1754-517X; Website: http://www.cardiff.ac.uk/clarc/jlarc
} 
Less is known about other areas of philosophy beyond the Organon, but Jacob of Edessa knew the Metaphysics ${ }^{53}$ and had an interest in physics, evident in his Hexaemeron, ${ }^{54}$ while Severus Sebokht was well versed in mathematics and in astronomy. ${ }^{55}$ It is impossible to tell whether the imbalance in their known writings between logic and the other areas accurately reflects their interest, or merely the accidental distribution of the available evidence, but if, like Sergius of Reshaina, they envisioned logic not as a part of philosophy but as its instrument, ${ }^{56}$ there would seem little point in studying the instrument without proceeding to at least some of the parts. Some of the evidence for their pre-Abbasid interest in logic comes, as was shown above, from the Paris Organon, but apart from the Leiden Physics (MS. Warner 583), which yields no such evidence, there is no comparable Arabic manuscript for the rest of the Aristotelian school corpus. The criticism of Aristotle's cosmology by John Philoponus, some at least of whose cosmological treatises were known to Jacob, ${ }^{57}$ may have tempered an enthusiasm for the study

on Aristotelian Logical Texts: The Syriac, Arabic and Medieval Latin Traditions (London, 1993), pp. 3-18. There is an extensive recent study on the oldest manuscript of them all, BL Add. 14,658, which includes references to earlier studies, by King, D., "Origenism in Sixth Century Syria. The Case of a Syriac Manuscript of the Pagan Philosophers," in: Fürst, A., (ed.), Origenes und sein Erbe in Orient und Okzident (Münster, 2011), pp. 179-212. My analysis of the motivation behind al-Fārābī's fanciful narrative is in Watt, "Al-Farabi and the History of the Syriac Organon," esp. pp. 771-8. I do not understand the point in (Tarán and) Gutas, Aristotle. Poetics, p. 86, n. 18 that "we have no evidence whatsoever of a school tradition of (the) study (of the last four books of the Organon) in Greek in late antiquity ... much less in Syriac." No late antique Greek commentaries (many of which were redacted students' lecture notes taken apo phōnēs) on these four are extant, but it is manifestly clear, both in Greek commentators and in Sergius, that they were prescribed for study within the curriculum, even though not considered as important as the first four of the usual sequence. There was, however, also an alternative sequence placing the Topics between the Prior and Posterior Analytics. Cf. Hadot, Simplicius, Commentaire sur les categories, fasc. I, pp. 81-4. Boethius translated the Topics and the Sophistical Refutations, though he found the latter particularly hard going. Cf. Ebbesen, S., "Boethius as a Translator and Aristotelian Commentator," in: Lössl, J. and J.W. Watt (eds.), Interpreting the Bible and Aristotle in Late Antiquity. The Alexandrian Commentary Tradition between Rome and Baghdad (Farnham, 2011), pp. 121-33. We have no evidence of any Greek commentary on Aristotle between around the time of Stephanus (floruit 610) and the eleventh century, although in Byzantium reading of late antique commentaries probably continued throughout the interim; cf. Sorabji, R., Aristotle Transformed (London, 1990), pp. 20-21. In Syriac, however, we have the evidence of the commentaries of George (d. 724), along with his translations, in the unique Dayr al-Suryan manuscript BL Add. 14,659.

${ }^{53}$ Furlani, G., "Di alcuni passi della Metafisica di Aristotele presso Giacomo d'Edessa," Rendiconti della Reale Accademia Nazionale dei Lincei. Classe di scienze morali, storiche e filologiche 5 (1921), pp. 268-73.

${ }^{54}$ Cf. Wilks, M., "Jacob of Edessa's Use of Greek Philosophy in his Hexaemeron," in: ter Haar Romeny, B. (ed.), Jacob of Edessa and the Syriac Culture of his Day (Leiden, 2008), pp. 223-38.

${ }^{55}$ Cf. Reinink, G. J., "Severos Sebokht," GEDSH, p. 368.

${ }^{56}$ Cf. Hugonnard-Roche, La logique, pp. 197-202.

${ }^{57}$ Cf. above, n. 54.

John Watt, "The Syriac Aristotle Between Alexandria and Baghdad," in: Journal for Late Antique Religion and Culture 7 (2013) 26-50; ISSN: 1754-517X; Website: http://www.cardiff.ac.uk/clarc/jlarc 
of Aristotle's physical treatises, but without adversely affecting an interest more generally in physics and mathematics.

There can be no doubt, however, that many of those who concerned themselves with Aristotle's logic were also interested in Dionysius. In his Hexaemeron Jacob of Edessa used both Philoponus and Dionysius, ${ }^{58}$ and Athanasius of Balad, the most prolific of the Aristotle translators, also made a translation of Dionysius. This was probably a revision of Sergius' version, and was probably itself further revised by Phocas of Edessa, whose version is the one preserved in most extant Syriac manuscripts of Dionysius. ${ }^{59}$ Phocas' preface to his translation affords a valuable insight both into this bilingual culture towards the end of the seventh century, and into the influence of Sergius' edition of Dionysius. Remarking that the writings of Dionysius, interpreted long ago from Greek to Syriac by Sergius in a translation "which all of us, Syrians, have read," he writes that "by divine providence" Dionysius has come into his hands in the original Greek with the scholia and preface of John of Scythopolis, and a preface by George of Scythopolis. He furthermore notes that many of the difficult words have been researched in the manuals which comment the Greek of the period and reported in the traditions of other workers such as Athanasius and Jacob of Edessa, those who have shown the route as much as possible and have joined the two languages. ${ }^{60}$

We cannot be sure that the Qenneshre scholars read both Aristotle and Dionysius as part of a curriculum embracing both, as in that presented by Sergius. Nevertheless, it is the case that such a curriculum constitutes a far more plausible reason for the study of Aristotle in Qenneshre than that sometimes offered to account for Syriac interest in his logic, namely its value for Christological controversy between rival Christian confessions. ${ }^{61}$ If Sergius' translation of Dionysius was known in Qenneshre

\footnotetext{
${ }^{58}$ Cf. Greatrex, M., "The Angelology in the Hexaemeron of Jacob of Edessa," Journal of the Canadian Society for Syriac Studies 4 (2004), pp. 33-46.

${ }^{59}$ Timothy, Ep. 43, p. 68 (text)/52 (version) Heimgartner; Brock, "Two Letters," pp. 237, 244.

${ }^{60}$ Cf. van Esbroeck, M., "La triple preface syriaque de Phocas," in: de Andia, Y. (ed.), Denys l'Aréopagite et sa postérité en Orient et en Occident (Paris, 1996), 171-2.

61 The view that the "pre-Abbasid Syrians" were interested in Aristotle primarily for his use in Christological controversy implies of course a radical disjunction between Sergius and these "preAbbasid Syrians". By contrast, Hugonnard-Roche, "Le mouvement des traductions syriaques," $p$ 71 observes that "S'il est un lieu de culture syriaque où l'entreprise, dont Sergius se fait le héraut, fut réalisée, c'est sans doute le monastère de Qenneshre ..., où Sévère Sebokt, autant que les sources nous permettent de le savoir, donna une impulsion remarquable à l'étude des textes grecs." While there is no reason to doubt the significant role of Severus (himself of Persian background) in the history of the monastery, its origins in Greek-speaking territory in the previous century make it likely that the study of Greek philosophy there antedates Severus. The evidence that Aristotelian logic played a significant role in Syriac Christological controversy is minimal or non-existent, while that that their interest in philosophy was for its own sake and consistent with that of the pagan Greek Neoplatonists, albeit Christianised, is plentiful in comparison; cf. King, D., "Why were the Syrians interested in Greek Philosophy?" in: Wood, P. (ed.), History and Identity in the Late Antique Near East (Oxford, 2013), pp. 61-82, and King, D., "Logic in the Service of Ancient John Watt, "The Syriac Aristotle Between Alexandria and Baghdad," in: Journal for Late Antique Religion and Culture 7 (2013) 26-50; ISSN: 1754-517X; Website: http://www.cardiff.ac.uk/clarc/jlarc
} 
before that made by Athanasius, we may reasonably suppose that Sergius' prologue was included in it, the Discourse on the Spiritual Life, where his Christianised version of the Alexandrian curriculum is presented. The close association of Aristotle and Dionysius also appears later (see below) in a Christian Arabic text from tenth century Baghdad. It is not possible at present to say whether or not there were Syrians who read works by the pagan Neoplatonists whom Sergius had "removed" to be replaced by Dionysius. The only certain evidence for a Syriac version of any of this material is that of quotations from the Enneads in Phocas' translation of John of Scythopolis' scholia to Dionysius, and some sayings of Plotinus wrongly attributed to Plato in a Syriac gnomology. ${ }^{62}$ However, the circles around Stephen bar Sudhaili, author of the Book of Hierotheos, and the Origenistic circles in which Evagrius of Pontus' works were much admired, are milieus in which it is possible to imagine that readers of Plotinus or Proclus might have existed. ${ }^{63}$ Although there is no further evidence of Syriac translations, it remains possible that bilingual Syriac speakers read them in Greek, and that the Arabic versions and adaptations which appeared in Abbasid times were derived from Greek manuscripts which had been read and copied in the Syrian-Mesopotamian area by bilingual Syrians. From Hunain's risāla on the Syriac and Arabic translations of Galen we know that Greek manuscripts of untranslated works of Galen were available in that area as well as the Syriac versions by Sergius of Reshaina of many of his writings, but since we have nothing comparable to that risāla relating to Neoplatonic philosophy, we can currently only speculate about manuscripts and readers of Plotinus and Proclus in the pre-Abbasid Near East.

The importance of the Qenneshre school lies not only in that it "bridges the gap" between the sixth century and the eighth (George bishop of the Arabs, the latest of the four Qenneshre scholars mentioned above, died in 724), but also that the translations by Athanasius were well known in eighth-to-tenth century Baghdad. The earlier witness is Timothy (probably born around 740), ${ }^{64}$ whose references in his letters to the translations of the Posterior Analytics and Topics were mentioned above, and the later witness the marginal readings in the Paris Organon. It is significant that Timothy also knew of Athanasius' and Phocas' translations of Dionysius, and was as keen to have copies of (either of) these as he was to have copies of texts of Aristotle and the Aristotelian commentators. ${ }^{65}$ Timothy himself had been educated in an East Syrian monastery, Bashosh near Mosul, but was

Eastern Christianity: An Exploration of Motives," Archiv für Geschichte der Philosophie (forthcoming).

${ }^{62}$ Frank, R. M., “The Use of the Enneads by John of Scythopolis," Le Muséon 100 (1987), pp. 101-8; Brock, “A Syriac Intermediary for the Arabic Theology of Aristotle?” pp. 296-7.

${ }^{63}$ Brock, "A Syriac Intermediary for the Arabic Theology of Aristotle?” pp. 301-6.

${ }^{64}$ For the date see Berti, V., Vita e studi di Timoteo I, patriarca cristiano di Baghdad (Paris and Leuven, 2009), pp. 135-6.

${ }^{65}$ Cf. above, n. 59.

John Watt, "The Syriac Aristotle Between Alexandria and Baghdad," in: Journal for Late Antique Religion and Culture 7 (2013) 26-50; ISSN: 1754-517X; Website: http://www.cardiff.ac.uk/clarc/jlarc 
anxious to locate as much as he could of Aristotle and Dionysius from the Syrian Orthodox monasteries of Mar Zina and Mar Mattai in that region, which suggests that in his day (i.e. the late eighth century) it was still in the libraries of Syrian Orthodox monasteries, of which Qenneshre was one, that the fullest resources for these studies could be found.

In subsequent years, Christians of Syrian tradition were active in philosophical circles in Baghdad, which was now clearly the centre of such studies, doubtless in some measure due to Timothy's own labours. ${ }^{66}$ Two groups can be identified. The earlier (ninth century) is that of the translators around Hunain and his son Ishāa. Hunain himself was primarily a doctor, but clearly also interested in philosophy. From his risāla on the translations of Galen, we know that the numerous Syriac translations by him and his associates were made for practising Syrian physicians, who dominated medical practice in ninth century Baghdad. Numerous Arabic translations were also made by this group, although not so many by Hunain himself, mostly from the Greek but sometimes, especially by those translators who were more proficient in Syriac than Greek, from an existing Syriac version. ${ }^{67}$ Although we have no corresponding missive on his Aristotelian translations, we have no reason to assume they differed from the Galenic translations. That is to say, the Syriac translations were made to be read by Syrians, the Arabic to be read by Arabs (whether Muslim or Christian). Ishāq seems to have translated more into Arabic than into Syriac, while the reverse is the case of his father. This doubtless indicates a shift over the period in the relative importance of the two languages in the realm of philosophy, but the fact that Ishāq translated the Posterior Analytics into Syriac (possibly revising the translation of Athanasius), but not Arabic, can be taken as evidence that it was particularly among Syrians that the Alexandrian tradition of the study of the Organon remained effective in Baghdad in his time. ${ }^{68}$

The later group (tenth century) is that around Abū Bišr Mattā, usually designated the Baghdad School (of Aristotelians). Unlike those around Hunain, they did not

${ }^{66}$ Cf. Berti, Vita e studi di Timoteo I, p. 331. The Syriac translations of Theophilus of Edessa (d. 785), which included the Prior Analytics and the Sophistical Refutations, are also indicative of an active Syriac readership for Aristotelian philosophy in Timothy's time. It is hardly credible that, as argued by Gutas in (Tarán and) Gutas, Aristotle. Poetics, p. 87, Timothy sought Syriac or Greek Aristotelian texts merely as Vorlagen for Arabic translations in order to satisfy the interests of "Muslim elites". Timothy's letters not only show his interest in the content of Aristotelian texts, but also his efforts to obtain Christian patristic texts at the same time and with the same vigour as he sought the Aristotelian. "Muslim elites" were not clamouring for Arabic versions of the Christian fathers. Cf. more fully my forthcoming "Syriac Aristotelian Tradition" (above, n. 18), section III.

${ }^{67}$ Cf. Strohmaier, "Ḥunain ibn Isḥāq. An Arab Scholar Translating into Syriac," pp. 163-70; Id., "Der syrische und der arabische Galen," ANRW II. 37, 2, pp. 1999-2011.

${ }^{68}$ Cf. Watt, J. W., "Why Did Hunayn, the Master Translator into Arabic, Make Translations into Syriac?" in Scheiner, J. and D. Janos (eds.), The Place to Go to. Contexts of Learning in Baghdad from the Eighth to Tenth Centuries (Princeton, forthcoming), and the articles cited in nn. 11 and 18 above.

John Watt, "The Syriac Aristotle Between Alexandria and Baghdad," in: Journal for Late Antique Religion and Culture 7 (2013) 26-50; ISSN: 1754-517X; Website: http://www.cardiff.ac.uk/clarc/jlarc 
know Greek, and when they made Arabic translations, they made them from the Syriac. The earliest Arabic version of the Posterior Analytics, for example, was translated by Mattā from Ishạa's Syriac version. ${ }^{69}$ They knew both the translations of Hunain's group and the earlier Syriac versions of Athanasius and of Theophilus of Edessa. Unlike Hunain, few if any of them were physicians, and they wrote numerous commentaries on the Aristotelian corpus, as far as we know mostly in Arabic. Among their pupils was the great Muslim philosopher al-Fārābī, who, as we have seen earlier, is often considered an important source for the process which we are trying to understand. But while in his work dealing with the appearance of philosophy in Islam, mentioned earlier as the basis of Meyerhof's theory, al-Fārābī tells what is more or less a fictional story involving anonymous personages, his account of the four named teachers of his own time is quite different. ${ }^{70}$ All of them were East Syrians. One of them, al-Marwazī, under whom Mattā studied, is reported in the Fihrist to have written about logic and other subjects only in Syriac. ${ }^{71}$ This last comment shows that right up to the period immediately before Mattā, Syriac remained in use as a medium of philosophical thought. The fact that the works of Quwairā, also a teacher of Mattā and the other writer among the four, "lacked fluency and were hard to understand" 72 might indicate that he was more at home in Syriac than in Arabic.

Aside from al-Fārābī, the two leading scholars from the School after Mattā were Yahyā ibn 'Adī and his pupil Ibn Zur'a, both Syrian Orthodox. Like Mattā they made translations from Syriac to Arabic, but as far as we know composed their philosophical works only in Arabic. The change of language did not however mean an abandonment of the main contours of the Syriac tradition. Inasmuch as the texts used for teaching in Mattā's school, that of the Baghdad Aristotelians, can be discerned from the information provided concerning texts and their translators in the Fihrist, Mattā's efforts were directed to the school corpus of Categories to Metaphysics taught at Alexandria, and among the Commentators principally to Alexander, Themistius, and Olympiodorus, two of the four previously noted as being of interest to Timothy. ${ }^{73}$ Aristotle, Metaphysics Lambda 9 on the triad of Mind, Thinking, and Thought was much used by the Christians of the Baghdad Aristotelians in their Trinitarian theology and apologetics, certainly from Yahyā ibn 'Adī onwards.

A short treatise by Yahyā̄'s pupil, Ibn Zur'a, reveals that an enquiry had been put to him as to why Christians spoke about Father, Son, and Holy Spirit rather than Mind, Thinking, and Thought (cf. Aristotle, Metaphysics Lambda 9). There

\footnotetext{
${ }^{69}$ Manțiq Arisțū, vol. 2, p. 309 Badawī; Fihrist, p. 249,11-12 Flügel, transl. p. 600 Dodge.

${ }^{70}$ Ibn Abī Ușaibi‘a, vol. II, pp. 135,16-19 Müller.

${ }^{71}$ Fihrist, p. 263,15-17 Flügel, trans. p. 629 Dodge.

${ }^{72}$ Fihrist, p. 262,31-2 Flügel, trans. p. 628 Dodge.

${ }^{73}$ Cf. Watt, J. W., "From Sergius to Mattā: Aristotle and Pseudo-Dionysius in Syriac Tradition," in: Lössl and Watt, Interpreting the Bible and Aristotle in Late Antiquity, pp. 252-5. John Watt, "The Syriac Aristotle Between Alexandria and Baghdad," in: Journal for Late Antique Religion and Culture 7 (2013) 26-50; ISSN: 1754-517X; Website: http://www.cardiff.ac.uk/clarc/jlarc
} 
is a clear implication here that Christian Baghdad Aristotelians considered some religious truths to be identical with those of Aristotelian philosophy, but that conventional religious language was figurative, an idea which may have been a source for al-Fārābī's more radical theory that religion itself was a symbolic representation of philosophy designed for the unphilosophical multitude. Ibn Zur'a answered the question in a conventional philosophical way differentiating the unworthy, for whom figurative language concealed the higher mysteries, from the worthy, whom it stimulated to achieve deeper insight by challenging them to inquire into the reasons for the choice of the figure. However, the authority he cited for this was, significantly, "the virtuous and excellent Dionysius,",74 probably alluding to the exposition in Celestial Hierarchy 2 of the use of poetic figures by the Scriptures to arouse and stimulate the minds of the pure. ${ }^{75}$ The interpretation of the Christian doctrine of the Trinity in the light of Metaphysics Lambda 9 was a significant feature in the thought of Yahyāa, ${ }^{76}$ who may also have read Dionysius, whether the inspiration for his concept of a triad of attributes (goodness, power, and wisdom) within the Unity of God came from Proclus himself or Dionysius. ${ }^{77}$ In the context of the entire Syriac philosophical tradition, these observations suggest that the seamless integration of Aristotle and Dionysius into a single curriculum culminating in a Christian Neoplatonic theology persisted all the way in Syriac from Sergius to the Baghdad Aristotelians.

Establishing a continuous Syriac tradition of study of Aristotle across these centuries does not necessarily imply that it was the only means by which Greek philosophy became known to Arab thinkers. Since Meyerhof's theory, another channel between Alexandria and Baghdad has been proposed by Michel Tardieu in the form of a pagan Platonic Academy in the Syriac-speaking city of Harran. The central contentions here are that the philosophers who fled Athens, Simplicius in particular, eventually settled in this largely pagan city where a Platonic Academy already existed, that a number of reports by Arab authors point to the presence of a Platonic institution there, and that the pagan Sabians from Harran among the scholars and translators of Abbasid Baghdad came from this institution. ${ }^{78}$ The thesis has been hailed with great enthusiasm in some quarters and sharply rejected

\footnotetext{
${ }^{74}$ Sbath, P. (ed.), Vingt traités philosophiques et apologétiques d'auteurs arabes chrétiens du IX au XIV siècle (Cairo, 1929), pp. 10-11.

${ }^{75}$ De Coel. Hier.2, 137A-B; 140A-B; 141B; 145A-B; 145C (p. 10,9-12; p. 11,11-20; p. 13,1318; p. 15,21-16,13; p. 16,19-17,2 Heil-Ritter).

${ }^{76}$ Cf. Platti, E., Yahyā ibn 'Adī: théologien chrétien et philosophe arabe (Leuven, 1983), p. 109; Endress, G., The Works of Yahyā ibn 'Adī (Wiesbaden, 1977), pp. 101-3.

${ }^{77}$ Endress, The Works of Yahyā ibn 'Ad̄̄, pp. 72-3.

${ }^{78}$ Tardieu, M., "Ṣābiens coraniques et Șābiens de Harrān,” Journal asiatique 274 (1986), pp. 144; Id., Les paysages reliques. Routes et haltes syriennes d'Isidore à Simplicius (Louvain and Paris, 1990).

John Watt, "The Syriac Aristotle Between Alexandria and Baghdad," in: Journal for Late Antique Religion and Culture 7 (2013) 26-50; ISSN: 1754-517X; Website: http://www.cardiff.ac.uk/clarc/jlarc
} 
in others. ${ }^{79}$ All that need be noted here is that any significant interaction between this alleged centre of pagan Neoplatonism and Christian monastic schools seems rather unlikely, and it is the concentration on Aristotle in the Syriac tradition, to the apparent virtual exclusion of Plato, which is replicated in the Aristotelian focus of Islamic philosophy. Although Plato's political philosophy was influential in both Christian and Muslim circles, probably through intermediaries such as Themistius or Galen's epitome of the Republic, very little of the Platonic corpus was known in Arabic, and the only persons named by the Fihrist as translators of his works are Hunain, Ishāa ibn Hunain, Yaḥyā ibn 'Adī, and Ibn al-Batrīq ${ }^{80}$ none of them from Harran. There are good grounds to suppose that the Harranians were important in the Abbasid era in the realms of mathematics and astronomy, ${ }^{81}$ however, their significance for the Arab appropriation of Aristotelian philosophy appears fairly minimal in comparison with the Christian Syriac. Among the numerous works attributed to their most significant scholar, Thābit ibn Qurra, who moved in the circle of al-Kindī, only a few are connected to the Aristotelian school corpus. ${ }^{82}$

Al-Kindī and his circle are clearly to be differentiated in some important ways from the Syriac Aristotelians. A contemporary of Hunain, al-Kindī clearly knew

\footnotetext{
${ }^{79}$ A prominent supporter is Hadot, I., "La vie et l'œuvre de Simplicius d'après des sources grecques et arabes," in: Hadot, I. (ed.), Simplicius: sa vie, son æevre, sa survie (Berlin, 1987), pp. 3-39; English version in Sorabji, Aristotle Transformed, pp. 275-303. Among the (probably more numerous) sceptics mention may be made of Lameer, J., "From Alexandria to Baghdad: Reflections of the Genesis of a Problematical Tradition," in: Endress, G. and R. Kruk (eds.), The Ancient Tradition in Christian and Islamic Hellenism (Leiden, 1996), pp. 181-92; Luna, C., Rev. R. Thiel, Simplikios und das Ende der neuplatonischen Schule in Athen, Mnemosyne 54 (2001), pp. 482-504; Lane Fox, R., "Harran, the Sabians, and the Late Platonist 'Movers'," in: Smith, A. (ed.), The Philosopher and Society in Late Antiquity (Swansea, 2005), pp. 231-44; and Watts, E., "Where to Live the Philosophical Life in the Sixth Century? Damascius, Simplicius, and the Return from Persia," Greek, Roman, and Byzantine Studies 45 (2005), pp. 285-315.

${ }^{80}$ Fihrist, p. 246,5-24 Flügel, trans. pp. 592-4 Dodge. There are also dubious explicit references to Olympiodorus and Qusța.

${ }^{81}$ Cf. Pingree, D., "The Șābians of Harrān and the Classical Tradition," International Journal of the Classical Tradition 9 (2002), pp. 8-35. Pingree supports the thesis of Tardieu, but the evidence he presents for the mathematical interests of the Harranians is not dependent upon it.

${ }^{82}$ The Fihrist mentions an epitome of De interpretatione and a partial commentary on Physics (p. 249,4 Flügel, trans. p. 599 Dodge; p. 250,24-5 Flügel, p. 603 Dodge), and a short exposition of the Metaphysics is extant (see below). The attribution to Thābit ibn Qurra (by a manuscript of the Hebrew translation of Themistius' commentary on Metaphysics Lambda) of a supporting role in the Arabic translation of the work is treated with some reserve by Brague, R., Thémistius. Paraphrase de la Métaphysique d'Aristote, Livre Lambda (Paris, 1999), pp. 16-17. The Fihrist also attributes to him a translation of Epaphroditus' Commentary on Aristotle's Account of the Halo of the Moon and the Rainbow (p. 254,14-16 Flügel, p. 612 Dodge). Most of his translations and works are in the fields of mathematics, astronomy, and medicine. Cf. Rashed, R. and M. Rashed (eds.), Sciences and Philosophy in 9th Century Baghdad. Täbit Ibn Qurra (826-901) (Berlin, 2009); and for his exposition of the Metaphysics, Reisman, D. C. and A. Bertolacci, "Tābit Ibn Qurra's Concise Exposition of Aristotle's Metaphysics: Text, Translation and Commentary," ibid., pp. 715-76.

John Watt, "The Syriac Aristotle Between Alexandria and Baghdad," in: Journal for Late Antique Religion and Culture 7 (2013) 26-50; ISSN: 1754-517X; Website: http://www.cardiff.ac.uk/clarc/jlarc
} 
some Aristotle, but far less than was known in the Syriac circles, and there is no evidence that the translators he commissioned recreated anything in Arabic that was comparable to the late antique Aristotelian curriculum. ${ }^{83}$ His knowledge of Aristotle was nevertheless a great deal more extensive than that of Plato, whom he knew mostly in extracts or epitomes. ${ }^{84}$ While most of his translators were Christian and probably, like Thābit, knew Syriac, they do not seem to have also made Syriac versions, as did those of the circle of Hunain. There is no doubt that al-Kindī's own thinking was more indebted to Neoplatonism, and in general more eclectic, than that of the Syriac Aristotelians, ${ }^{85}$ and he cannot therefore be considered to stand directly in the line of the Syriac Aristotelian tradition. However, this does not necessarily mean that that tradition did not have a significant impact upon him, even if indirectly. Some treatises of Aristotle were important to him, and this interest among Muslims Arabs of the ninth century CE in some of his works - but not the complete corpus of the Alexandrian curriculum - which is manifested earlier, for example, in the well-known commission of al-Mahdi to Timothy for an Arabic version of the Topics, is unlikely to have arisen quite independently of the fact that Syrians in the same locality had a long and continuing tradition of the study of Aristotle. Al-Kindī's work on The Quantity of all the Books of Aristotle (like that of the earlier Logic [al-Mantiq] of Ibn al-Muqaffa') may have been based on a Syriac compendium. ${ }^{86}$

More important to al-Kindī, however, was The Theology of Aristotle, an adapted and enlarged Arabic translation of Enneads IV-VI. ${ }^{87}$ The translation is due to Ibn Nā'ima, from whom al-Kindī commissioned a number of Aristotelian translations. There is no evidence of a Syriac version, but, as mentioned earlier, portions of the Enneads were translated into Syriac in the seventh century in John of Scythopolis's scholia to Dionysius, by Phocas of Edessa. All the sources of the adaptations to Plotinus have not yet been identified, but Aristotle was certainly one of them, and

${ }^{83}$ Cf. Watt, "Why Did Hunayn, the Master Translator into Arabic, Make Translations into Syriac?" esp. the sections entitled "The Circles of Hunayn and al-Kindi" and "The Translation of the Commentators on Aristotle".

${ }^{84}$ Cf. Endress, G., "Building the Library of Arabic Philosophy. Platonism and Aristotelianism in the Sources of al-Kindi," in D'Ancona, The Libraries of the Neoplatonists, pp. 327-33.

${ }^{85}$ Cf. ibid., pp. 333-50.

${ }^{86}$ Cf. (Tarán and) Gutas, Aristotle. Poetics, pp. 88-9. On Ibn al-Muqaffa' and the Syriac tradition, cf. Hugonnard-Roche, H., "L'intermédiaire syriaque dans la transmission de la philosophie grecque à l'arabe: Le cas de l'Organon d'Aristote," Arabic Sciences and Philosophy 1 (1991), pp. 203-4. On al-Mahdī's commission to Timothy, cf. my article "Syriac Translators and Greek Philosophy in Early Abbasid Iraq," Journal of the Canadian Society for Syriac Studies 4 (2004), pp. 15-26 [= Rhetoric and Philosophy from Greek into Syriac (Farnham, 2010), chapter XIII].

${ }^{87}$ Cf. Endress, "Building the Library of Arabic Philosophy," pp. 333-4.

John Watt, "The Syriac Aristotle Between Alexandria and Baghdad," in: Journal for Late Antique Religion and Culture 7 (2013) 26-50; ISSN: 1754-517X; Website: http://www.cardiff.ac.uk/clarc/jlarc 
a good argument has been made that Dionysius was another. ${ }^{88}$ It has also been proposed that Ibn Nā'ima from Emesa, who, it can be assumed, would have been familiar with Dionysius, was not only the translator, but also the author of the adaptations. ${ }^{89}$ One cannot but wonder whether the Theology was envisaged by alKindī as a Muslim, or at least non-Christian or neutral, counterpart to Dionysius. ${ }^{90}$

Al-Fārābī, an alumnus of the school of the Baghdad Aristotelians, wrote that "everything comprised by this science" - in effect his own philosophy - "was expounded in the Greek language, then in the Syriac language, then in the Arabic language." "91 Inasmuch as he was himself an Aristotelian philosopher, al-Fārābī’s assessment was a valid one, and points to the Syro-Arabic Baghdad School of Mattā and its Syriac antecedents as the foundation of his own thought, but works that came into Arabic through the circle of al-Kindī also contributed to it, and, as we have seen, whether or not they circulated (possibly in Greek) among Syrians before their appearance in Arabic is uncertain. Scholarship is divided as to whether al-Fārābī's works should be chronologically separated into an earlier and a later phase, based on an apparent difference between, respectively, works presenting a creationist cosmology, and works presenting emanationist thinking. In the former al-Fārābi more closely resembles the Christian Aristotelian commentators, in the latter the pagan Neoplatonists, but the alternative position to the developmental view interprets the "creationist" works (if accepted as authentic) in the light of the more systematic and markedly Neoplatonic treatises. ${ }^{92}$ However this is resolved, with regard to our original question it appears that with al-Fārābī the story that began with Sergius has come full circle. It is not clear what texts al-Fārābī had at his disposal which would have brought him close to the system of Proclus, but (part of) Proclus' Commentary on the Timaeus and his Examination of Aristotle's Objections to Plato's Timaeus preserved in Philoponus' Contra Proclum may have been available in Arabic. ${ }^{93}$ But whatever his source, in the more systematic works the elaborate metaphysics of pagan Neoplatonism is to some extent restored.

In late antique (sixth century) Alexandria Sergius of Reshaina broke from the Hellenic Neoplatonism of his pagan masters and linked Aristotle into a curriculum

${ }^{88}$ Cf. D’Ancona, C., “Il terma della docta ignorantia nel platonismo arabo', in: Piaia, G. (ed.), Concordia Discors (Padua, 1993), pp. 3-22; Adamson, P., The Arabic Plotinus (London, 2002), pp. 106-9, 162-5.

${ }^{89}$ Cf. Adamson, The Arabic Plotinus, pp. 171-7.

${ }^{90}$ Cf. Hugonnard-Roche, "Le mouvement des traductions syriaques," p. 71.

${ }^{91}$ Taḥșill, p. 88 al-Yāsīn; trans. p. 43 Mahdi.

${ }^{92}$ Cf. Janos, D., Method, Structure, and Development in al-Fārābì’s Cosmology (Leiden, 2012), pp. 235-332, with the literature referred to there on each view. Janos himself argues for "the developmentalist hypothesis" and considers the work just quoted, Taḥsĭl al-sa 'äda, to belong to the later phase.

${ }^{93}$ Cf. Vallat, P., "Al-Fārābī's Arguments for the Eternity of the World and the Contingency of Natural Phenomena," in: Lössl and Watt, Interpreting the Bible and Aristotle in Late Antiquity, pp. 281-4.

John Watt, "The Syriac Aristotle Between Alexandria and Baghdad," in: Journal for Late Antique Religion and Culture 7 (2013) 26-50; ISSN: 1754-517X; Website: http://www.cardiff.ac.uk/clarc/jlarc 
with the Bible and Dionysius. Around four centuries later in Baghdad, al-Fārābī broke from the Dionysian Aristotelianism of his Christian masters and reinstated the old Hellenic Neoplatonism. ${ }^{94}$

\author{
Abbreviations \\ AKM Abhandlungen für die Kunde des Morgenlandes (Leipzig-Wiesbaden) \\ ANRW Aufstieg und Niedergang der römischen Welt (Berlin) \\ CAG Commentaria in Aristotelem Graeca (Berlin) \\ CSCO Corpus Scriptorum Christianorum Orientalium (Leuven) \\ GEDSH Gorgias Encyclopedic Dictionary of the Syriac Heritage (Piscataway, 2011) \\ PTS Patristische Texte und Studien (Berlin)
}

\title{
Primary Sources
}

Ammonius

In Porphyrii Isagogen Commentarius, ed. A. Busse, CAG IV, 3 (Berlin, 1891)

In Aristotelis Categorias Commentarius, ed. A. Busse, CAG IV, 4 (Berlin, 1895)

Dionysius

Corpus Dionysiacum, vol. 1, ed. B. R. Suchla, PTS 33 (Berlin, 1990)

Corpus Dionysiacum, vol. 2, ed. G. Heil, A. M. Ritter, PTS 36 (Berlin, 1991)

al-Fārābī

Tahṣìl al-sa 'āda, ed. J. al-Yāsīn (Beirut, 1981). English Translation by M. Mahdi, Alfarabi's Philosophy of Plato and Aristotle (Ithaca, 1969/2001)

\section{Fihrist}

Kitāb al-Fihrist, ed. G. Flügel (Leipzig, 1871). English Translation by B. Dodge, The Fihrist of Ibn al-Nadìm (New York, 1970)

Hunain

Risāla: G. Bergsträsser, Hunain ibn Isḥāq. Über die syrischen und arabischen Galen-

Übersetzungen, AKM 2 (Leipzig, 1925)

Ibn Abī Ușaibi’a

'Uyūn al-anbā' fì tabaqāt al-ațtibā', ed. A. Müller (Cairo- Königsberg, 1882-1884)

John of Scythopolis

\footnotetext{
${ }^{94}$ Cf. ibid., p. 285: "In this scheme [of al-Fārābī], the attribution of the final-formal causality to the First and Second Causes and that of the efficient-afficient causality to the Active Intellect and the celestial bodies ... owes little to Aristotle and Alexander and almost all to Ammonius and beyond him to Proclus."

John Watt, "The Syriac Aristotle Between Alexandria and Baghdad," in: Journal for Late Antique Religion and Culture 7 (2013) 26-50; ISSN: 1754-517X;

Website: http://www.cardiff.ac.uk/clarc/jlarc
} 
Scholia: Migne, Patrologia Graeca IV

Manțiq Arisțū

Manțiq Arisțū, ed. A. Badawī (Cairo, 1948-1952)

Olympiodorus

Prolegomena et In Aristotelis Categorias Commentarium, ed. A. Busse, CAG XII, 1 (Berlin, 1902)

Philoponus

In Aristotelis Categorias Commentarium, ed. A. Busse, CAG XIII, 1 (Berlin, 1898)

Proclus

In Platonis Timaeum Commentaria, ed. E. Diehl (Leipzig, 1903-1906)

Théologie Platonicienne, Livre I, ed. H.D. Saffrey and L.G. Westerink (Paris, 1968)

Simplicius

In Aristotelis Categorias Commentarium, ed. C. Kalbfleisch, CAG VIII (Berlin, 1907)

Sergius

Sherwood, P., "Mimro de Serge de Rešayna sur la vie spirituelle," L'Orient syrien 5 (1960), pp. 433-57; 6 (1961), pp. 95-115, 121-56

Timothy, Patriarch I

Timothei Patriarchae I epistulae, ed. O. Braun, CSCO 74 /75 (Leuven, 1914/1915)

Die Briefe 42-58 des Ostsyrischen Patriarchen Timotheos I, ed. M. Heimgartner,

CSCO 644 (Textedition)/645 (Einleitung, Übersetzung und Anmerkungen) (Leuven, 2012) 